\title{
G Protein Pathway Suppressor 2
}

National Cancer Institute

\section{Source}

National Cancer Institute. G Protein Pathway Suppressor 2. NCI Thesaurus. Code C26248.

G protein pathway suppressor 2 (327 aa, $\sim 37 \mathrm{kDa}$ ) is encoded by the human GPS2 gene. This protein is involved in the regulation of G-protein and mitogen-activated protein kinase-mediated signal pathways. 